\title{
ULASAN BUKU: FIQH OF CONTEMPORARY FINANCIAL AND BANKING TRANSACTIONS*
}

\begin{abstract}
Ahmad Hidayat Buang**
Buku ini merupakan himpunan kertas kerja penulis yang dibentangkan di pelbagai seminar antarabangsa berkaitan perbankan dan kewangan Islam. Terdapat 12 tajuk yang pilih khusus oleh penulis untuk dijadikan bab-bab perbincangan di dalam buku ini. Kesemua tajuk ini merupakan kemaskini dengan tambahan editing dari segi perbincangan dan bahan-bahan rujukan yang digunakan. Daripada 12 tajuk yang dibincangkan, terdapat satu tajuk perbincangan berkenaan persoalan riba yang menjadi asas perbezaan utama antara perbankan Islam dan perbankan konvesional. Manakala satu tajuk menyentuh ciri-ciri dan peranan Jawatakuasa Syariah Perbankan Islam.

Tajuk ini merupakan percubaan awal oleh mana-mana penulis untuk mengulas fungsi sesebuah Jawatan Syariah institusi perbankan Islam. Satu tajuk ialah cadangan penulis terhadap instrument pelaburan dalam pengurusan dan pembiayaan utiliti awam. Baki 9 tajuk yang lain menyentuh produk dan akad-akad yang digunakan dalam sistem kewangan dan perbankan Islam

* Nazih Hammad, Fiqh of Contemporary Financial and Banking Transactions (n.p.: alBaraka Banking Group, Circa 2006). Buku ini mengandungi 545 halaman dengan cetakan berkulit keras.

** Professor, Department of Shariah and Law, Academy of Islamic Studies, University of Malaya, 50603 Kuala Lumpur. hidayat. buang@gmail.com
\end{abstract}


masa kini seperti muwata'ah, qalb al-dayn (debt conversion), tawarruq, mu'āwadah (janji dalam pertukaran matawang masa hadapan), akad iz'an (adhesion), jaminan dalam deposit pelaburan, muqāṣah, sukuk ijārah, ijārah kepada penjual. Tidak dapat dinafikan kebanyakan persoalan-persoalan ini sudah banyak dibincangkan oleh banyak penulis lain dan pengkaji. Namun penulis telah memasukkan dalam penulisannya asas-asas prinsip Syariah serta rujukan-rujukan utama. Perkara ini amat berguna dan membantu kepada pengkaji-pengkaji dan pengamal baru dalam bidang kewangan dan perbankan Islam untuk memahami bagaimana asas-asas dan prinsip-prinsip Syariah serta rujukanrujukan yang digunakan diaplikasikan dalam produk-produk kewangan. Perkara yang paling penting ialah penjelasan penulis tentang metodologi penulisannya di halaman 3-21.

Metodologi yang digunakan oleh penulis dalam penulisannya tidaklah mengikut dasar mana-mana mazhab, namun merupakan campuran pelbagai pendekatan dan kaedah ușüliyyah. Selepas rujukan asasi kepada al-Quran dan al-Sunnah, penulis menyenaraikan pendekatan dan kaedah yang digunakan, iaitu (1) menyemak dan meneliti pandangan-pandangan dalam mazhab berdasarkan kepada kekuatan hujah mereka bagi menentukan pandangan yang terbaik, (2) bagi masalah yang tidak dinyatakan dalam nas atau terdapat ijtihad ulama, maka perkara tersebut akan digali jawapannya berdasarkan dalil-dalil yang bersesuaian. Tidak jelas bagaimana penyelesaian masalah ini akan dilakukan. Namun penjelasan kaedah-kaedah seterusnya memberi gambaran bagaimana penyelesaian akan dilakukan, (3) Dengan memetik pandangan Qarafi di dalam kitab al-Furuq penulis menjelaskan beliau tidak akan menerima pendangan yang berasaskan kepada 'urf masa dulu yang mana konteksnya telah berubah kerana memberi fatwa berasaskan konteks yang tidak lagi relevan adalah bersalahan dengan ijma ' (h.6).

Manakala baki kaedah atau pendekatan seterusnya adalah merupakan pemakaian prinsip-prinsip umum Syariah seperti maqāsid, mashaqqah, ma'alat dan bersederhana dalam fatwa. Dalam menyokong penggunaan prinsip-prinsip ini penulis memetik sokongan daripada pelbagai penulis dalam bidang Usul al-Fiqh dan maqāṣid seperti Izz al-Din, Zaruq, Syatibi, Ibn Taymiyyah, Ibn al-Qayyim dan Ibn 'Asyur. Sungguhpun penulis 
menyatakan beliau akan merujuk kepada pelbagai rujukan dan ulama dalam penelitiannya, namun melalui pembacaan terhadap bab-bab perbincangan mendapati kebanyakan rujukan bergantung kepada Ibn Taymiyyah dan Ibn al-Qayyim ataupun penulisan dalam mazhab Hanbali dan juga Maliki. Rujukan kepada keduadua mazhab ini banyak dibuat oleh pihak sektor perbankan Islam kerana dasar-dasar mazhab berkenaan yang bersesuaian dengan perubahan dan fleksibiliti urusan perniagaan seperti prinsip kebebasan membuat syarat dalam mazhab Hanbali dan pemakaian 'urf secara lebih terbuka dalam mazhab Maliki.

Antara penemuan atau rumusan penulis terhadap topik-topik perbincangan adalah seperti berikut:

1. Berasaskan perbincangan oleh ahli-ahli fiqh terdapat sebelas bentuk riba iaitu (1) riba haqiqi, (2) ruba hukmi (secara asasnya kedua-dua bentuk riba ini adalah sama sahaja iaitu melibatkan pertukaran barangan ribawi secara tangguh atau berlebihan), (3) riba halal yakni pemberian hadiah bagi mendapatkan sesuatu pulangan dalam urusniaga - penggunaan nama ini agak mengelirukan kerana seolah-olah menghalalkan riba, namun maksud halal di sini ialah pemberian atau hadiah dari peminjam atau apa yang dikenali sebagai hibatul madin kepada pemiutang (hal.52-4), (4) riba al-ajlan (bayaran pinjaman melalui hasil pertanian), (5) riba al-fadl, (6) riba al-qurud, (7) riba al-muzabanah, (8) riba al-nasa', (9) riba al-nasi'ah (perbezaan antara al-nasa' dan al-nasi'ah ialah yang pertama terhad kepada pertukaran barangan ribawi secara bertangguh, manakala kedua ialah penambahan kepada hutang akibat kelewatan membayarnya.

Secara umumnya, kedua-duanya mempunyai persamaan dengan riba al-qurud melainkan riba al-nasi' ah meliputi juga kedua-dua hutang dan jual beli), (10) riba al-naqd (hanya melibatkan matawang) dan (11) riba al-yadd iaitu penangguhan penyerahan pertukaran barangan riba. Pembahagian kepada riba kepada 11 ini melihat kepada jenis barangan atau transaksi yang berbeza, sungguhpun pada dasarnya kesemuanya dapat disimpulkan kepada tiga iaitu penangguhan (nasi' $a h$ ), perbezaan $(f a d l)$ dan penyerahan $(y a d d)$. 
2. Tawarruq seperti yang diamalkan oleh perbankan Islam kini merupakan satu bentuk muwata'ah (مواطئة) yang dibenarkan (h.92) Mengikut penulis muwata 'ah dalam konteks tawarruq bermaksud persetujuan antara pihak-pihak di luar akad bagi penggunaan akad-akad yang sahih bagi tujuan mencari penyelesaian yang sah mengikut undang-undang Syariah (h.135). Menggunakan definisi ini, penulis berpandangan instrumen kewangan moden seperti Murabahah Purchased to Orderer atau MPO (h.101), al-Ijārah Thumma al-Bay ' atau AITAB (h.102), Commodity Murabahah (h.103) dan surat kredit (h.105) merupakan satu bentuk muwata'ah.

Penulis seterusnya meletakkan syarat-syarat atau kawalan (dawabit) bagi pemakaian muwata'ah terutama di dalam akadakad kewangan Islam yang berbentuk hybrid atau komposit, iaitu (1) tidak boleh digunakan pada akad-akad yang dilarang oleh Shariah (2) tidak boleh digunakan sebagai hilah bagi mengelak larangan riba, (3) tidak boleh digunakan sebagai cara untuk mengelak larangan riba dan (4) tidak boleh digunakan kepada dua atau lebih akad-akad yang bertentangan tujuannnya seperti gabungan antara akad qard dan mudārabah atau antara ju 'alah dan salam (h.121). Tidak dapat dipastikan bagaimana untuk mengelak pelanggaran syarat-syarat ini kerana tujuan instrument-instrumen di atas adalah sebagai alternatif kepada mekanisme perbankan konvensional yang hanya berbeza dalam bentuknya sahaja. Begitu juga agak sukar untuk membezakan justifikasi muwata'ah ini dengan penggunaan hilah, kerana kedua-duanya memberi kesan yang sama di dalam akad-akad moden perbankan Islam.

3. Apabila seseorang pelanggan bank tidak dapat menunaikan pembayaran balik pembiayaannya kepada Bank, beberapa alternatif diberikan sebagai penyelesaian kepada masalah ini. Antaranya melalui proses yang dikenali sebagai debt conversion atau debt restructuring. Terdapat kontroversi pada proses ini kerana pada pandangan mazhab jumhur ianya satu bentuk riba nasi'ah kerana melibatkan penangguhan hutang ke satu masa hadapan baik sama ada jumlah hutang itu ditambah atau tidak. Bagi penulis proses debt conversion 
ini adalah bersamaan dengan apa yang dikenali di dalam fiqh Maliki sebagai Faskh al-Dayn serta kemudiannya diistilahkan oleh Ibn Taymiyyah sebagai Qalb al-Dayn (h.151). Daripada analisis yang dilakukan oleh penulis terhadap karya-karya fiqh mazhab mendapati terdapat lima bentuk qalb al-dayn yang dua darinya disepakati sebagai haram.

Penulis bersetuju dengan pandangan yang membenarkan Qalb al-Dayn kerana hujah qiyās yang digunakan oleh mazhab jumhur terhadap jual beli al-kali" adalah tidak bertepatan dengan bentuk urusniaga ini serta tidak terdapat larangan jelas dari Syarak mengenainya. Bahkan terdapat persamaan urusniaga ini dengan athar sahabat yang menyelesaikan hutang si mati melalui jualan barangan pusaka kepada pemiutang. Penulis juga berpendapat amalan perbankan Islam yang menawarkan modal baru kepada pelanggan sebagai penyelesaian kepada hutang lama dibenarkan dengan syarat tiada penambahan kepada hutang lama dan tiada hilah digunakan bagi menghalalkan sesuatu yang haram. Perkara ini tidak dapat dielakkan untuk menjaga kepentingan perbankan Islam daripada risiko dan bahaya (h172-3). Di sini sekali lagi penulis menyokong pandangan mazhab yang membolehkan Qalb al-Dayn dengan alasan mașlahah.

4. Penulis berpandangan Tawarruq Tersusun atau Organized Tawarruq seperti yang diamalkan oleh perbankan Islam kini adalah sah dengan syarat penjualannya kepada pihak ketiga tidak mempunyai apa-apa hubungan dengan pihak Bank. Manakala lima syarat yang diletakkan oleh penulis semasa melakukan tawarruq yang disifatkannya sebagai pengabungan akad-akad atau tarkib fi al- 'uqūd, pada pandangan saya perkara ini tidak berlaku kepada tawarruq kerana ia hanya merupakan siri-siri akad jual beli secara tangguh dan secara lani. Namun begitu bagi mengelak pemakaian pandangan Ibn Taymiyyah dan Ibn al-Qayyim yang melarang tawarruq secara tersusun (h.196), penulis berpandangan bentuk tawarruq yang diamal oleh pihak perbankan Islam masa kini adalah satu bentuk akad yang baru yang mempunyai ciri-cirinya yang khusus. Oleh yang demikian, akad sedemikian adalah patuh Syariah. 
Tambahan pula jikalau tawarruq ini tidak disusun sebegini rupa maka pihak perbankan Islam boleh mengalami kerugian (h.221-2). Pandangan penulis di sini adalah satu contoh di mana kepentingan umum diutamakan dalam aktiviti perbankan Islam.

5. Dalam perniagaan bank bayaran diambil di atas beberapa perkhidmatan yang secara tradisionalnya bayaran tidak dibenarkan. Sebagai contoh bayaran kepada kafalah pada pandangan sesetengah ulama tidak dibenarkan. Alasan larangan berkenaan kerana faedah daripada akad berkenaan tidak mempunyai nilai kewangan (h.249). Menolak pandangan ini, penulis menyatakan keadaan urusniaga pada masakini telah berubah dan oleh yang demikian bayaran perkhidmatan kepada akad kafalah atau daman seperti yang diamalkan oleh perbankan masa kini adalah dibenarkan kerana perkhidmatan yang diberikan itu mempunyai nilai kewangan (h.250).

Dengan melakukan analogi kepada pelbagai pandangan ulama khususnya dari mazhab Maliki dan Hanbali yang melihat larangan sesuatu jual beli tersebut tidak hanya melihat kepada objeknya, namun kepada tujuannya atau faedahnya, maka pengenaan bayaran kepada sesuatu janji atau tanggungan pada masa hadapan seperti dalam amalan hedging tukaran wang adalah dibenarkan. Penulis juga merujuk kepada prinsip maqāșid yang mana larangan kepada urusniaga sedemikian akan menyebabkan kesusahan dan kesulitan kepada masyarakat Islam (h.269-70). Pandangan penulis dalam perkara ini adalah lebih ringkas dan mudah daripada justifikasi perundangan amalan tukaran wang Islam masa hadapan atau $F X$ Islamic SWAP yang melibatkan penggunaan akad jual beli șarf, murābahah dan wa'ad.

6. Kerelaan dalam akad merupakan asas utama dalam undangundang Syariah. Oleh itu akad akan terbatal apabila terdapat paksaan kepada pembeli atau penjual. Namun dalam perundangan moden, negara-negara Arab yang terpengaruh dengan prinsip undang-undang kontrak Peranchis satu bentuk akad yang dikenali dengan adhesion contract telah 
diperkenalkan (terdapat penulis barat yang menterjemahkannya dengan administrative contract). Kontrak adhesion ini bermaksud terma-termanya ditentukan oleh undangundang atau mahkamah dan pihak-pihak tidak mempunyai kekebebasan sebagaimana dalam kontrak jual beli biasa. Topik sebegini bukanlah di bawah perbincangan produk kewangan Islam, kerana ia lebih kepada perbincangan prinsip-prinsip perundangan obligasi undang-undang negara Arab timur tengah. Oleh itu perbincangannya adalah berbentuk akademik bagi menunjukkan perkembangan dan penerimaan fiqh Islam terhadap prinsip-prinsip kontemporari undang-undang kontrak barat terutama melalui fatwa Akademi Fiqh OIC pada tahun 2003 yang membenarkan kontrak sebegini (h.317).

7. Pengusaha dalam akad mudāarabah tidak bertanggungjawab kepada kerugian perniagaan mudārabah. Pelabur atau pemodal yang akan menanggung kerugian berkenaan kecuali dalam beberapa keadaan seperti kecuaian oleh pihak pengusaha. Perbankan Islam di Malaysia dan juga di dunia Islam yang lain menerima pakai prinsip ini dalam kontrak mud̄ārabah. Penulis melalui kajiannya menolak kefahaman ini dan menegaskan dalam kesimpulan kajiannya bahawa larangan memasukkan syarat dalam akad mudārabah di mana pengusaha bertanggungjawab membayar ganti rugi perniagaan mud̄arabah adalah kuat. Bahkan, alasan ulama yang membolehkan syarat berkenaan adalah lebih kuat daripada kalangan yang melarangnya (h.356).

Mengenai kritikan yang menyatakan pandangan ini jika dilaksanakan akan mempunyai bentuk yang sama dengan pinjaman konvensional. Penulis menolak dakwaan ini dengan menyatakan terdapat perbezaan ketara antara syarat jaminan mudārabah dan pinjaman konvensional di mana tiada kadar faedah tambahan terhadap modal dikenakan dalam akad mudārabah berbanding pinjaman konvensional (h.349-50). Pandangan ini jika diterima akan menyebabkan perbankan Islam terutama di Malaysia boleh menawarkan kembali akaun simpanan mud̄arabah dengan jaminan pulangan simpanan di samping memperolehi jangkaan keuntungan yang lebih tinggi. 
Apa yang menarik di dalam perbincangan di bawah tajuk ini ialah teori kontrak Islam iaitu sebarang syarat tambahan yang bertentangan dengan maksud akad (muqtada al-'aqd) akan menyebabkan syarat atau akad itu sendiri terbatal. Penulis menyatakan pandangan ini bukan sesuatu yang mutlak, bahkan ia merupakan topik yang menjadi perselisihan di kalangan ulama (h.344). Bagi memperkuatkan hujahnya penulis memetik pandangan Imam Suyuti yang menyatakan tidaklah menjadi kesalahan jika seseorang mengikut pandangan yang menjadi perselisihan di kalangan ulama, yang menjadi kesalahan ialah tidak menerima pandangan yang dipersetujui secara $i j m \bar{a}^{*}$ (h.328).

8. Dalam perbincangan mengenai urusan pinjaman bersaling (reciprocal loans) dan muqāṣah, isu yang menarik perhatian ialah penggunaan kaedah mazhab Maliki dari pandangan Ibh Majishun di mana sesuatu yang berkecenderungan kepada haram itu dimaafkan dan dibolehkan jika ianya bukan sesuatu yang menjadi amalan atau lumrah. Alasan yang diberikan kerana dalam keadaan sedemikian tiada niat untuk melakukan perbuatan yang ditegah (h373). Alasan ini adalah sesuatu yang subjektif dan penggunaannya dalam perbankan Islam akan membolehkan penyelesaian beberapa masalah secara ad hoc yang bersifat terpencil.

Manakala tajuk sukuk ijārah, peranan majlis penasihat Syariah dan cadangan pelaburan utiliti awam sudah banyak dibincangkan dan oleh itu tidak perlu diulang di sini. Perbincangan mengenai menyewa asset kepada penjual asset secara umumnya termasuk dalam perbincangan muwata'ah seperti di dalam tawarruq di mana ianya dibolehkan dengan merujuk pandangan dalam mazhab Maliki dan Ibn Taymiyyah (h.508). Kebanyakan pandanganpandangan sebagaimana yang dibincangkan oleh penulis seperti di atas sudah diadaptasi oleh perbankan Islam di Malaysia, bahkan dimasukkan dalam polisi dokumen Bank Negara Malaysia yang berkaitan dengan kontrak-kontrak perbankan Islam.

Prinsip qalb al-dayn sepatutnya boleh diaplikasikan kepada moratorium pembayaran balik pembiayaan kewangan Islam barubaru ini tidak dilaksanakan kerana mendapat arahan daripada 
pihak kerajaan. Keadaan ini sungguhpun boleh menyebabkan kerugian kepada pihak perbankan Islam, namun langkah-langkah telah diambil bagi mengatasinya melalui pengurusan risiko yang efektif dan berpandangan ke hadapan melalui polisi dokumen tadbir urus Syariah BNM 2019. 
Jurnal Fiqh, Vol. 17 No. 2 (2020) 309-318 